\title{
Restenosis and its determinants in first and repeat coronary angioplasty
}

\author{
H. J. Rapold*, P. R. David, P. Guiteras Val, A. L. Mata, P. A. Crean and M. G. Bourassa \\ Department of Medicine, Montreal Heart Institute, 5000 East Bélanger Street, Montreal, Quebec, Canada \\ HIT IC8 and *Section of Cardiology, Department of Medicine, University of Berne Medical School, \\ Inselspital, 3010 Berne, Switzerland
}

KEY WORDS: PTCA, restenosis, repeat PTCA, PTCA outcome determinants.

Restenosis is the main problem limiting long-term success of percutaneous transluminal coronary angioplasty (PTCA) and is most accurately evaluated by follow-up angiography. We compared the primary and long-term results of angioplasty in 268 consecutive patients (293 segments) with first PTCA (PTCA 1, angiographic follow-up 98\%) and in 66 patients ( 76 segments) with repeat PTCA after restenosis (PTCA 2, angiographic follow-up 92\%). Forty clinical, angiographic and procedural factors were assessed in relation to outcome. Primary success rate was higher in PTCA $2(91 \%$ vs $67.5 \%)$ and major complications were fewer (4.5\% vs $16 \%)$. Higher inflation pressure $(7.9 \pm 2.3$ vs $6.8 \pm 1.8 \mathrm{~atm}, P<0.005)$ and larger balloons $(3.5 \pm 0.5$ vs $3.2 \pm 0.5 \mathrm{~mm}, P<0.005)$ were used for $P T C A 2$, resulting in lesser residual stenosis (33 $\pm 16 \%$ vs $40 \pm 18 \%$, $P<0.05)$. Restenosis rate $(\geqslant 70 \%)$ after PTCA 1 and after PTCA $2(27 \%$ vs $36 \%, P=N S)$ and the mean time to recurrence ( $4 \cdot 7$ vs $5 \cdot 3$ months, $P=N S$ ) were similar. Procedural factors were the main determinants of long-term success in primary $P$ TCA. The restenosis risk was independently related to residual stenosis $\geqslant 45 \%$ $(P<0.001)$, variant angina $(P<0.05)$ and multivessel disease $(P<0.05)$ after PTCA 1 and to male sex $(P<0.001)$ and higher inflation pressure $(P<0.05)$ after $P$ TCA 2 . Mild to moderate intimal tearing was associated with less restenosis after PTCA 1, but not after PTCA 2. Including 9 patients (10 segments) with a third PTCA, 70\% of the 66 patients with repeat PTCA had a successful long-term outcome. Repeat angioplasty should therefore be considered as an integral part of PTCA therapy. Restenosis however remains a major concern. An optimal primary result with a minimal residual stenosis is decisive for first PTCA, whereas avoidance of a dissection by using lower inflation pressure on a restenosis might improve the long-term outcome of repeat PTCA.

Since its introduction ${ }^{[1.2]}$ successful percutaneous transluminal coronary angioplasty (PTCA) has been shown to relieve angina and myocardial ischaemia as assessed by exercise electrocardiography ${ }^{[3]}$, thallium scintigraphy $y^{[3,4]}$, and measurement of coronary blood flow and myocardial metabolism ${ }^{[5,6]}$. The original indications ${ }^{[2]}$ have been expanded ${ }^{[7-17]}$. But regardless of selection criteria, restenosis with recurrence of myocardial ischaemia and symptoms remains the major problem limiting

Submitted for publication on 23 June 1986 and in revised form 21 October 1986.

For the period that this work was carried out, Dr Rapold was supported by a grant of the Swiss National Science Foundation.

Address for correspondence: Dr Hans J. Rapold, Section of Cardiology, Department of Medicine, University of Berne, Medical School, Inselspital, CH-3010 Berne, Switzerland. long-term success of PTCA. Reported restenosis rates $(14-47 \%)$ vary, depending in part on the definition used, but according to the larger series ${ }^{[18-22]}$, one patient in three with successful PTCA must expect recurrence, most of them within 6-8 months after the intervention. Repeat PTCA has been done with a higher primary success rate and fewer complications than the initial procedure. Nevertheless, there remains a substantial rate of second recurrences ${ }^{[23-25]}$.

The presence of angina as an indicator for restenosis has a predictive accuracy of only $56 \%$ after first and $67 \%$ after second PTCA according to the NHLBI report ${ }^{[18.23]}$. One patient in four with restenosis has no chest pain. In a population at high risk of restenosis, such as in patients undergoing repeat PTCA, a higher percentage of angiographic follow-up than that so far reported $(48 \%$ and $61 \%$, respectively) ${ }^{[23,24]}$ might therefore be mandatory, in 
order to evaluate the value of a repeat procedure, as stated in the NHLBI repor ${ }^{[18.23]}$ and by others ${ }^{[26]}$.

This study, based on an angiographic follow-up of $98 \%$ and $92 \%$, respectively, of the patients, reports on our long-term results of first and of repeat PTCA. Factors related to restenosis after both conditions and their impact on procedural recommendations are discussed.

\section{Methods}

\section{STUDY POPULATION (REPEAT PTCA)}

Between February 1980 and February 1984, 609 consecutive patients underwent PTCA at the Montreal Heart Institute. Among them 66 patients, 52 men and 14 women, had a second PTCA (PTCA 2 ) on the same coronary segment because of restenosis after an initially successful procedure.
Ten patients had a repeat PTCA on two segments. Nine patients underwent a third PTCA (PTCA 3) because of restenosis on an initially successful second PTCA, one of them on 2 segments. Figure 1 summarizes results and follow-up of the patients with repeat angioplasty.

\section{REFERENCE POPULATION (FIRST PTCA)}

Among our first consecutive 268 angioplasties (February 1980 until March 1983) 181 were primarily successful and 178 of them $(98 \%)$ had an anglographic follow-up. Since that time, we have not performed control angiography systematically on patients with a first successful and uncomplicated PTCA of a single coronary vessel, that are asymptomatic and had a negative stress test in their follow-up. To avoid a bias by the selection of

PTCA 2 primory results

PTCA 2 long-term results

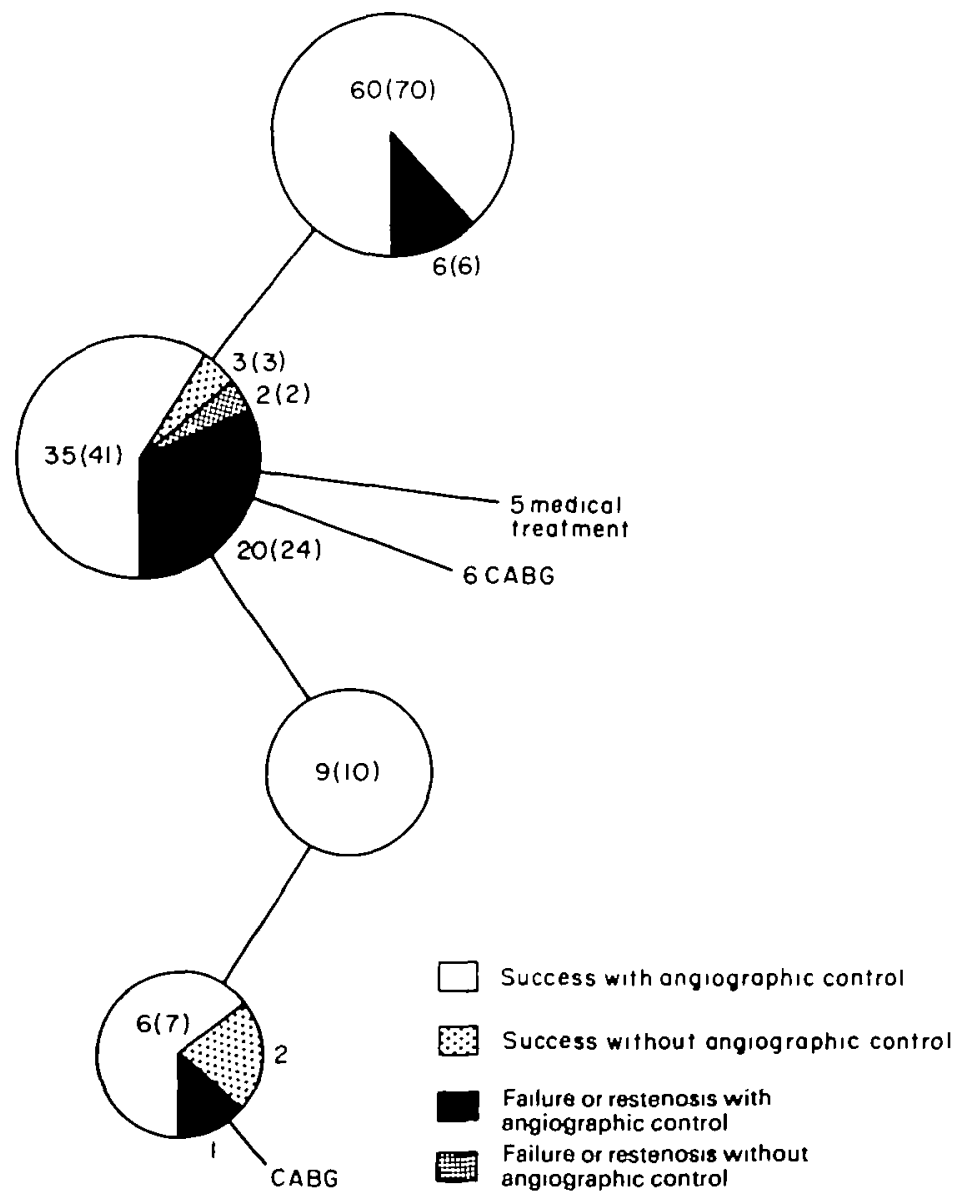

PTCA 3 primary results

PTCA 3. long-term results

Success with angiogrophic control

Success without ongiographic control

Failure or restenosis withou

angiographic control

Figure 1 Results and follow-up of repeat PTCA in 66 patients ( 76 coronary segments). 
Table I Variables entering univariate analysis

Clinical

Angiographic

Procedural

\begin{tabular}{|c|c|c|}
\hline Age & Extent CAD (1-2-3 vessel disease) & Number of segments attempted \\
\hline Sex & Regional left ventricular wall motion & Catheter type \\
\hline History of smoking & Left ventricular ejection fraction & Pre and post PTCA gradient \\
\hline cholesterol $>250 \mathrm{mg} \mathrm{dl}^{-1}$ & Stenosis: site (LAD, CX, RCA, graft; & Largest balloon used \\
\hline triglycendes $>170 \mathrm{mg} \mathrm{dl}^{-1}$ & prox, mid/distal) & Maximal inflation pressure \\
\hline hypertension & seventy $(\%)$, pre- and post-PTCA & Number of inflations \\
\hline diabetes & morphology (discrete, tubular, & Ratio of diameters inflated \\
\hline CAD in the family & diffuse) & balloon/nondiseased artery \\
\hline History of pnor MI & geometry (concentric, excentric) & Coronary dissection (mild, \\
\hline prior CHF & calcification & moderate, severe, occlusion) \\
\hline CABG & involved branch & Complications \\
\hline unstable angina & Collaterals & \\
\hline Duration of angina & & \\
\hline Duration of actual level of angina & & \\
\hline Angina: stable on effort & & \\
\hline unstable, excl variant & & \\
\hline variant & & \\
\hline Hospital stay & & \\
\hline Post PTCA treatment & & \\
\hline
\end{tabular}

angiographically controlled patients, we compare therefore our repeat PTCA with the first consecutive 268 initial procedures.

Table 1 shows the forty clinical, angiographical and procedural variables assessed for their discriminant and predictive value of primary and long-term success in PTCA 1 and PTCA 2.

\section{PTCA PROCEDURE AND ADJUNCTIVE THERAPY}

Angioplasty was performed by femoral approach following a previously described protocol ${ }^{[27]}$ and using steerable catheters since April 1982. The percent severity of the stenosis pre- and post-PTCA was evaluated angiographically in several angulations. In addition, the absolute luminal diameter of the adjacent healthy coronary segment was measured pre-PTCA, corrected for X-ray magnification by comparing it with the shadow of the $8 \mathrm{~F}$ catheter $(2.7 \mathrm{~mm})$. Since the real balloon size exceeds the one given by manufacturers with pressures above 6 atmospheres ${ }^{[28]}$, the balloons were measured immediately after the procedure, inflated at the maximal pressure used. As a consequence of previous analyses ${ }^{[29]}$ the inflation pressure used tended to be higher (8-12 atm) and balloons larger during 1984 with the goal of achieving a ratio of $1 \cdot 1$ to 1.3 in the diameters of inflated balloon/adjacent healthy coronary segment, which we believe to be optimal $^{[28]}$.
All patients were treated with platelet-inhibitors (either sulfinpyrazone $200 \mathrm{mg}$ q.i.d. or aspirin $650 \mathrm{mg}$ plus dipyridamole $75 \mathrm{mg}$ t.i.d.) for six months after successful PTCA. Diltiazem, $90 \mathrm{mg}$ t.i.d. in addition to anti-platelet treatment was given systematically for 3 months during a randomized trial in $1982 / 1983^{[30]}$ but, based on physicians' preference, only intermittently since.

\section{FOLLOW-UP}

The mean clinical follow-up after PTCA 1 was

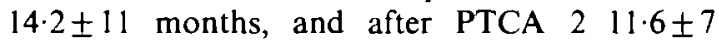
months. It included exercise stress tests, usually at 3 and 6 months after the intervention. No patient was lost to follow-up. 178 of the 181 patients with a successful PTCA $1(98 \%)$ had a control angiography $10.6 \pm 6.8$ months after the intervention, and so did 55 of the 60 patients $(92 \%) 9 \pm 7$ months after a successful PTCA 2. Six patients refused control angiography. In 2 patients it was not done after PTCA 2 because of complications previously.

The time of angiographic control was chosen to compare the time interval to recurrence after and repeat PTCA, since the information on reappearance of symptoms, especially in the presence of persisting atypical pains, was not precise in a number of cases. Control angiography, however, was done early (within 1-4 weeks) after reappearance of symptoms. 
CRITERIA FOR SUCCESS AND RESTENOSIS

Primary success of PTCA was defined as $\geqslant 20 \%$ stenosis reduction without a major inhospital complication.

Restenosis was defined as reappearance of a successfully dilated stenosis to $\geqslant 70 \%$ in the angulation showing maximum severity of the lesion. Each restenosis definition, including those proposed by the NHLBI, have shortcomings as shown by comparing them to each other ${ }^{[18]}$. Our restenosis definition is based on a percent severity that we believe to be of clinical relevance. With an angiographic follow-up of $98 \%$ for the PTCA 1 population and of $92 \%$ for the redilated patients, assessment of short and long term success is based exclusively on angiographic data, unless otherwise mentioned.

\section{STATISTICAL ANALYSIS}

To compare baseline and follow-up characteristics, univariate analysis was performed using the chi-square test for categorical data and the Student $t$-test for continuous data. A stepwise logistic regression analysisidentified among the univariately significant variables those with an independent discriminant or predictive value, using primary success and restenosis (definitions above) as outcome variables. BMDP software was used for statistical testing.

\section{Results}

\section{PATIENT CHARACTERISTICS}

The baseline characteristics of both PTCA 1 and PTCA 2 patients are shown in Table 2. Sixty-six patients underwent a second intervention for restenosis $4 \cdot 7 \pm 4$ months after the first one. Their mean age was 53.4 years. Seventy-nine percent were men. Fourteen percent had suffered a prior myocardial infarction and $9 \%$ had undergone previous coronary artery bypass grafting (CABG). Stable angina on effort was present in $63 \%$, whereas $37 \%$ of the patients were in an unstable condition, including $12 \%$ with variant angina ${ }^{[31]}$. One vessel disease was present in $83 \%$ and abnormal regional left ventricular wall motion in $30 \%$.

Although the mean age was higher in the population that underwent repeat PTCA compared to the PTCA 1 population $(53.4 \pm 10$ vs $50.8 \pm 10$ years, $P=0.05$ ), the percentage of patients above 60 years in both groups was not significantly different. There was a trend for more men and more variant angina in the PTCA 2 group, but no other significant difference in the baseline characteristics of the patients.

\section{REPEAT PTCA PROCEDURE}

Compared to the first PTCA in the same patients several factors of the second procedure changed significantly (Table 3): larger balloons (mean $3.5 \mathrm{~mm}$ vs $3.2 \mathrm{~mm}, P<0.005)$ with a higher ratio of diameters inflated balloon/nondiseased artery (mean 1.04 vs $0.95, P=0.07$ ) and higher inflation pressure (mean 7.9 vs 6.8 atmospheres $P<0.005$ ) were used. The resulting residual stenosis was less (mean $33 \%$ vs $40 \%, P<0.05$ ).

\section{PRIMARY RESULTS OF PTCA 1/PTCA 2 AND THEIR PREDICTORS}

The immediate outcome of both PTCA 1 and PTCA 2 is summarized in Table 4 . The primary success rate of PTCA 2 was $91 \%(60 / 66)$ of the patients and $92 \%(70 / 76)$ of the segments which was significantly higher than in the PTCA 1 population $(181 / 268$ patients $=67 \cdot 5 \%$ and $205 / 293$ segments $=$ $70 \%$, respectively). Failures were due to inability to

Table 2 Baseline characteristics of the pattents with first and repeal PTCA

\begin{tabular}{|c|c|c|}
\hline \multirow{2}{*}{$\begin{array}{l}\text { No. of } \\
\text { patients (coronary segments) }\end{array}$} & \multirow{2}{*}{$\frac{\text { PTCA 1 }}{268(293)}$} & \multirow{2}{*}{$\frac{\text { PTCA } 2}{66(76)}$} \\
\hline & & \\
\hline Age (years) & $50 \cdot 6 \pm 9 \cdot 7$ & $53 \cdot 4 \pm 10$ \\
\hline Men & $73 \%$ & $79 \%$ \\
\hline Prior myocardial infarction & $13 \%$ & $14 \%$ \\
\hline Prior bypass graft & $6 \%$ & $9 \%$ \\
\hline Stable effort angina & $69 \%$ & $63 \%$ \\
\hline Unstable (excl variant) angina & $23 \%$ & $25 \%$ \\
\hline Variant angina & $8 \%$ & $12 \%$ \\
\hline Single vessel disease* & $85 \%$ & $83 \%$ \\
\hline Multivessel disease* & $15 \%$ & $17 \%$ \\
\hline $\mathrm{LAD}$ & $65 \%$ & $63 \%$ \\
\hline LCX & $8 \%$ & $14 \%$ \\
\hline RCA & $23 \%$ & $20 \%$ \\
\hline CABG & $4 \%$ & $3 \%$ \\
\hline Abnormal regional wall motion & $23 \%$ & $30 \%$ \\
\hline
\end{tabular}

$* 70 \%$ stenosis on major coronary artery or $\geqslant 50 \%$ on left main stem.

LAD - left anterior descending, LCX-circumflex, RCA - right coronary artery, CABG - coronary artery bypass graft. 
Table 3 Differences between first and second procedures in patients with repeat PTCA $(N=66$ putients or 76 coronary' segments)

\begin{tabular}{lccc}
\hline & PTCA 1 & PTCA 2 & $P$ value \\
\hline $\begin{array}{lccc}\text { Largest balloon used (mm) } \\
\text { Maximal inflation pressure (atm) }\end{array}$ & $3.2 \pm 0.5$ & $3.5 \pm 0.5$ & $<0.005$ \\
$\begin{array}{l}\text { Residual stenosis (\%) } \\
\text { Ratio of diameters inflated balloon/ } \\
\quad \text { undiseased artery }\end{array}$ & $40.0 \pm 1.8$ & $7.9 \pm 2.3$ & $<0.005$ \\
& $095 \pm 0.2$ & $1.04 \pm 0.2$ & $=0.07$ \\
\hline
\end{tabular}

Table 4 Results of first and repeat PTCA

\begin{tabular}{|c|c|c|c|c|}
\hline & \multicolumn{2}{|c|}{ PTCA 1} & \multicolumn{2}{|c|}{ PTCA 2} \\
\hline & $N$ & $\%$ & $N$ & $\%$ \\
\hline $\begin{array}{l}\text { All patients (coronary segments) } \\
\text { primary success } \\
\text { failure: lesion non traversed } \\
\text { non dilatable } \\
\text { occluded } \\
\text { complications: in hospital death } \\
\text { infarction } \\
\text { emergency CABG } \\
\text { one of the above }\end{array}$ & 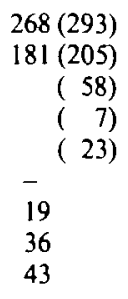 & $\begin{array}{l}100 \\
67 \cdot 5(70) \\
\quad(20) \\
\quad(2) \\
\quad(8) \\
-\quad \\
7 \\
13 \\
16\end{array}$ & $\begin{array}{l}66(76) \\
60(70) \\
(3) \\
- \\
(3) \\
- \\
2 \\
1 \\
3\end{array}$ & $\begin{array}{l}100 \\
91(92) \\
\quad(4 \cdot 5) \\
\quad- \\
\quad(4.5) \\
-\quad \\
3 \\
1.5 \\
4.5\end{array}$ \\
\hline $\begin{array}{l}\text { Patients (coronary segments) with } \\
\text { angiographic control } \\
\text { long term success } \\
\text { restenosis }\end{array}$ & $\begin{array}{r}178(202) \\
130(154) \\
48(48)\end{array}$ & $\begin{array}{l}100 \\
73(76) \\
27(24)\end{array}$ & $\begin{array}{l}55(65) \\
35(41) \\
20(24)\end{array}$ & $\begin{array}{l}100 \\
64(63) \\
36(37)\end{array}$ \\
\hline
\end{tabular}

cross the stenosis $(4 \cdot 5 \%$ in PTCA $2,20 \%$ in PTCA 1), early occlusion ( $4.5 \%$ in PTCA $2,8 \%$ in PTCA 1) and nondilatable lesions (none in PTCA 2, 2\% in PTCA 1).

Significantly fewer major complications occurred due to PTCA 2 compared to PTCA 1 (myocardial infarction $3 \%$ vs $7 \%$, emergency coronary artery bypass grafting $1.5 \%$ vs $13 \%$, no in hospital death; overall $4.5 \%$ vs $16 \%, P<0.05$ ).

Due to considerable improvement in PTCA materials since 1982 (steerable catheters, low profile balloons) and growing experience (e.g. in the decision to perform emergency bypass grafting) the primary results in the PTCA 1 group do not reflect the present standard and should therefore only cautiously be compared with the PTCA 2 group. Nevertheless, the primary results in the PTCA 2 subgroup treated during the same period as the
PTCA 1 group (Feb 1980-March 1983: $N=35$, success rate $32 / 35=91 \%$, major complications $1 / 35=2 \cdot 9 \%$ ) had already reached that excellent standard.

Factors that were independently related to primary success in our PTCA 1 group are not mentioned here, since they might no longer be relevant with the new materials available. The number of failures in the PTCA 2 group is too small to evaluate factors influencing the immediate outcome.

\section{LONG-TERM RESULTS OF PTCA 1/PTCA 2 AND THEIR PREDICTORS}

Restenosis $\geqslant 70 \%$ was angiographically documented in $48 / 178(27 \%)$ patients or $48 / 205(24 \%)$ coronary segments at a mean of $4.7 \pm 4$ months after successful PTCA 1. The use of the NHLBI definition of restenosis ${ }^{[18]}$ would have added two more 
Table 5 Factors significanily related to restenosis after first PTCA

\begin{tabular}{|c|c|c|c|c|}
\hline & $N$ & $\begin{array}{l}\text { Restenosis } \\
\text { rates, except }\end{array}$ & $\begin{array}{l}\text { Lasting success } \\
\text { rates, except }\end{array}$ & $P$ value \\
\hline \multicolumn{5}{|l|}{ Overall results } \\
\hline \multicolumn{5}{|l|}{ Univariate analysis of subgroups } \\
\hline $\begin{array}{l}\text { Coronary lesion: } \begin{array}{l}\text { one vessel disease, fixed } \\
\text { one vessel d. + variant angina } \\
\text { multıvessel disease }\end{array}\end{array}$ & $\begin{array}{r}134 \\
20 \\
24\end{array}$ & $\begin{array}{l}20 \% \\
45 \% \\
46 \%\end{array}$ & $\begin{array}{l}80 \% \\
55 \% \\
54 \%\end{array}$ & $<0005$ \\
\hline $\begin{aligned} & \text { Coronary dissection by PTCA. } \text { no } \\
& \text { mild } \\
& \text { moderate } \\
& \text { severe }\end{aligned}$ & $\begin{array}{l}(110) \\
\left(\begin{array}{l}19) \\
(64) \\
(9)\end{array}\right.\end{array}$ & $\begin{array}{l}(27 \%) \\
(5 \%) \\
(17 \%) \\
(55 \%)\end{array}$ & $\begin{array}{l}(73 \%) \\
(95 \%) \\
(83 \%) \\
(45 \%)\end{array}$ & $<0.01$ \\
\hline $\begin{aligned} \text { Calcification artery: yes } \\
\text { no }\end{aligned}$ & $\begin{array}{l}(50) \\
(152)\end{array}$ & $\begin{array}{l}(34 \%) \\
(20 \%)\end{array}$ & $\begin{array}{l}(66 \%) \\
(80 \%)\end{array}$ & $<0.05$ \\
\hline Ratıo diameter inflated balloon/artery & $(202)$ & $* 0.98 \pm 0.2$ & $* 1.06 \pm 0.2$ & $<0.05$ \\
\hline Number of inflations with largest balloon & $(202)$ & $* 5 \cdot 1 \pm 2 \cdot 9$ & $* 4 \cdot 2 \pm 2 \cdot 4$ & $<0.05$ \\
\hline $\begin{array}{l}\text { Multivariate analysis } \\
\text { Residual stenosis } \geqslant 45 \% \\
\text { Coronary lesion: one vessel disease with variant a } \\
\text { Coronary dissection by PTCA: none or severe } \\
\text { Ratio of diameters inflated balloon/artery }<1\end{array}$ & a or multive & isease & & $\begin{array}{l}P \text {-value } \\
<0.001 \\
<0.05 \\
\leqslant 0.07 \\
=0.07\end{array}$ \\
\hline
\end{tabular}

patients. $84 \%$ of the restenoses occurred within 6 months, $96 \%$ within 8 months. The restenosis rate after PTCA 2 tended to be higher: $20 / 55(36 \%)$ patients or $24 / 65(37 \%)$ segments $(P=\mathrm{NS}$ for patients, $=0.05$ for segments). The mean interval to restenosis after PTCA 2 was $5 \cdot 3+5$ months, with $76 \%$ of the recurrences within 6 months and $88 \%$ within 8 months after the intervention $(P=\mathrm{NS} v \mathrm{~s}$ PTCA 1).

Factors that favoured restenosis after PTCA 1 according to uni- and multivariate analysis of 40 variables (Table 1) are listed in Table 5. The restenosis group was characterized by a higher degree of residual stenosis immediately after PTCA (mean $48 \pm 14 \%$ with $29 / 48$ segments between 50 and $60 \%$ vs mean $36 \pm 13 \%$ with only $28 / 154$ segments between 50 and $60 \%$ in the group with lasting success, $P<0.001$ ), a smaller ratio in the diameters of inflated balloon/adjacent healthy coronary segment $(0.98 \pm 0.2$ vs $1.06 \pm 0.2, P<0.05)$ and more inflations $(5 \cdot 1 \pm 2.9$ vs $4.2 \pm 2.4 \quad P<0.05)$. Other factors predicting a high restenosis rate were: variant angina $(45 \%)$, multivessel disease $(46 \%)$, a calcified artery $(34 \%)$ and a severe intimal dissection $(55 \%)$. Interestingly, a mild dissection led to significant less restenosis than no visible dissection (5\% vs $27 \%$, $P<0.01)$. Among variables not related to restenosis were the coronary risk factors, the clinical antecedents, gender and age. The multivariate analysis selected three independent predictors of restenosis after PTCA 1: a residual stenosis of $45 \%$ or more $(P<0.001)$, the presence of variant angina $(P<0.05)$ and multivessel disease $(P<0.05)$. The degree of dissection produced by PTCA and the ratio in diameters of inflated balloon/artery almost reached statistical significance ( $P=0.07$ each).

The same forty variables (Table 1) were assessed for their predictive value of restenosis after PTCA 2 (Table 6). The restenosis group was characterized by the use of higher inflation pressure $(9 \pm 2$ vs $7 \pm 2 \mathrm{~atm}, P<0.005)$ and a high initial gradient (57 \pm 15 vs $45 \pm 15 \mathrm{mmHg}, P<0.05$ ). Only men 
Table 6 Factors stgnificantly related to restenosis after repeat PTCA

\begin{tabular}{|c|c|c|c|c|}
\hline & $N$ & $\begin{array}{l}\text { Restenosis } \\
\text { rates, except }\end{array}$ & $\begin{array}{l}\text { Lasting success } \\
\text { rates, except* }\end{array}$ & $P$ value \\
\hline $\begin{array}{l}\text { Overall results } \\
\text { Patients (coronary segments) with angiographic } \\
\text { control after successful PTCA } 2\end{array}$ & $55(65)$ & $36 \%(37 \%)$ & $64 \%(63 \%)$ & \\
\hline $\begin{array}{l}\text { Univariate analysis of subgroups } \\
\text { Sex: male } \\
\text { female }\end{array}$ & $\begin{array}{l}43 \\
12\end{array}$ & $\begin{array}{r}47 \% \\
0 \%\end{array}$ & $\begin{array}{r}53 \% \\
100 \%\end{array}$ & $<0.001$ \\
\hline Inflation pressure & $(62)$ & $* 8.9 \pm 2.4 \mathrm{~atm}$ & $7 \pm 1.9 \mathrm{~atm}$ & $<0.005$ \\
\hline $\begin{aligned} \text { Coronary dissection by PTCA: } & \text { no } \\
& \text { mild } \\
& \text { moderate }\end{aligned}$ & $\begin{array}{l}(35) \\
(26) \\
(4)\end{array}$ & $\begin{array}{l}(26 \%) \\
(42 \%) \\
(100 \%)\end{array}$ & $\begin{array}{l}(74 \%) \\
(58 \%) \\
(0 \%)\end{array}$ & $<0.01$ \\
\hline $\begin{aligned} \text { Extent of coronary disease one vessel } & \begin{array}{l}\text { multivessel } \\
\text { mula }\end{array}\end{aligned}$ & $\begin{array}{l}35 \\
20\end{array}$ & $\begin{array}{l}23 \% \\
60 \%\end{array}$ & $\begin{array}{l}77 \% \\
40 \%\end{array}$ & $<005$ \\
\hline Initial gradient before PTCA & 49 & $* 57 \pm 15 \mathrm{mmHg}$ & $* 45 \pm 15 \mathrm{mmHg}$ & $<0.05$ \\
\hline $\begin{array}{l}\text { Multivariate analysis } \\
\text { Male sex } \\
\text { Inflation pressure }>8 \mathrm{~atm}\end{array}$ & & & & $\begin{array}{l}P \text { value } \\
<0.001 \\
<0.05\end{array}$ \\
\hline
\end{tabular}

suffered a second recurrence (restenosis rate $47 \%$ vs $0 \%$ for female, $P<0.001$ ). Other factors related to a high restenosis risk were: a mild or moderate intimal dissection (restenosis rate $42 \%$ and $100 \%$, respectively, vs $26 \%$ with no dissection, $P<0.05$ ) and multivessel disease $(60 \%$ vs $23 \%$ in one vessel disease, $P<0.05$ ). The trend of a higher recurrence rate in patients with prior unstable $(57 \%)$ or variant angina $(50 \%)$ was not significant, probably because of the small size of the subgroups $(N=14$ and 6 , respectively).

Multivariate analysis retained male sex $(P<0.001)$ and a higher inflation pressure $(P<0.05)$ as indepedent predictors of restenosis after PTCA 2.

When the clinical results of patients without angiographic control ( 3 asymptomatic, 2 atypically symptomatic but with positive exercise stress test) are taken into account, the recurrence rate after PTCA 2 does not change $(22 / 60=36 \cdot 6 \%)$.

\section{THIRD PTCA}

Of the 20 patients with a second recurrence after PTCA 2, 9 underwent a third PTCA (PTCA 3), 6 had elective coronary artery bypass grafting and 5 were controlled with medical treatment (see Fig. 1). PTCA 3 was primarily successful in all patients. Follow-up based on angiograms (6 patients), exer- cise stress tests ( 1 patient) and interviews ( 2 patients) demonstrated sustained success and absence of symptoms in 8 of 9 patients. One patient, with 3 consecutive PTCAs and restenoses on the proximal segment of a venous bypass graft had a reoperation.

Thus, analyzing PTCA 2 and 3 together, repeat angioplasty in 66 patients with restenosis after the first intervention resulted in lasting success in $70 \%$ of them (41 of 58 patients with angiographic followup or 46 of all 66 patients with clinical follow-up).

\section{Discussion}

\section{PATIENTS}

The patients undergoing repeat PTCA had baseline characteristics similar to the patients with single or initial PTCA. The trend of more men having a second angioplasty is in line with the other two series published so $\mathrm{far}^{[23.24]}$. The high incidence of variant angina in PTCA 2 patients might be due to our research interest in that area ${ }^{[17.31]}$ and the high restenosis rate among those patients ${ }^{[17]}$.

\section{PROCEDURE}

The fact that larger balloons with higher inflation pressure were used for the second PTCA, leading to a higher ratio of diameters inflated balloon/ nondiseased artery and lesser residual stenosis, 
reflects our ${ }^{[28]}$ and others ${ }^{[32,33]}$ experience, that these procedural factors are more important determinants of immediate PTCA success than the clinical or angiographic pattern.

\section{PRIMARY RESULTS}

A second PTCA, performed because of restenosis had a higher primary success rate than a first procedure (91 vs $67.5 \%$, much like that in the other series $\left(85 \%\right.$ vs $61 \%{ }^{[23]}, 97$ vs $85 \%{ }^{[24]}, 96 \%{ }^{[26]}$. Major complications were fewer, also in agreement with published reports ${ }^{[23,24]}$. The reasons for both include the improvement in PTCA material since 1982, the increasing experience of the operators and the selection of a PTCA 2 population with lesions suitable for a successful intervention. The primary results of our PTCA 1 group 1980-1983 certainly do not reflect the current standard. Furthermore the number of patients (especially of failures) in PTCA 2 group is small. Factors influencing the immediate outcome of both PTCA 1 and PTCA 2 are therefore not discussed here.

\section{LONG-TERM RESULTS}

Restenosis remains a major concern limiting long-term success of both first and repeat PTCA in spite of improved primary results. The lowest published restenosis rate in a larger series with an angiographical follow-up comparable to ours was $17 \%$ after initial and $33 \%$ after repeat PTCA $^{[20]}$. In most other series of first PTCA a higher recurrence rate between $25 \%$ and $35 \% \%^{[18,19,21,22]}$ was documented with a less complete angiographic follow-up, but in agreement with the $27 \%$ of our PTCA 1 group.

The restenosis rate tends to be even higher after repeat PTCA $(36 \%)$, as shown by others as well ${ }^{[23-25]}$. This is also true for the PTCA 2 performed since March 1983, and therefore independent of technical improvement, but not surprising for a selected population at high risk of restenosis. In the NHLBI study ${ }^{[23]} 24 \%$ of the patients had clinical events and $52 \%$ were symptomatic after a second PTCA. In the Atlanta experience ${ }^{[24]}, 26 \%$ of the patients were not improved clinically after a mean of 8.5 months. The Mid America Heart Institute reported a higher restenosis rate $(37 \%)$ after repeat angioplasty ${ }^{[25}$. With an angiographic followup of $48 \%{ }^{[23]}$ and $61 \%^{[24]}$ (not detailed in ${ }^{[25]}$ ), the restenosis rates $\left(34 \%{ }^{[23]}, 41 \%^{[24]}, 37 \%{ }^{[25)}\right.$ in these respective series might not be representative of the total PTCA 2 population. If, as suggested by the Atlanta study ${ }^{[24]}$, the mean time interval between intervention and recurrence lengthens after repeat
PTCA, a more complete angiographical follow-up might have revealed restenoses not yet clinically apparent. In our study, however, the time to recurrence was similar after PTCA 1 (4.7 \pm 4 months) and PTCA $2(5 \cdot 3 \pm 5$ months) with $96 \%$ and $85 \%$ of the restenoses being demonstrated within 8 months after the intervention.

\section{RESTENOSIS RISK FACTORS}

\section{Non procedural factors}

Unstable and especially variant angina independently increased the restenosis risk after primary PTCA, in agreement with other reports ${ }^{[18,21]}$. Multivessel disease was related to restenosis after both first and repeat PTCA (cf ref. ${ }^{[2]}$ ). Male sex was a strong risk factor of recurrence after repeat PTCA. This contrasts with the higher bypass patency reported in men ${ }^{[34,35]}$, but confirms the

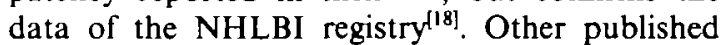
associations with a high restenosis risk, such as diabetes ${ }^{[18.22]}$, PTCA of occluded vessels ${ }^{[14.21]}$ or PTCA of a proximal vein graft stenosis ${ }^{[13,36]}$ could not be verified due to small subgroups in our series. Dilated stenoses on the left anterior descending artery did not recur more often than those on the circumflex or the right coronary artery, as reported by others ${ }^{[21,22]}$; the use of an adequate balloon size after measuring the luminal diameter of the adjacent healthy coronary segment (see Methods) might have prevented this.

\section{Procedural factors}

Procedural factors of PTCA seem to be the main determinants of its long term outcome.

The residual stenosis, especially when $\geqslant 45 \%$, was the main predictor of restenosis after first PTCA. The importance of the immediate result has been emphasized by other groups as well ${ }^{[21,22]}$. A severe intimal dissection increased the recurrence risk, but no visible dissection as well. We believe like others $^{[21,22]}$ that mild intimal tearing is an angiographic marker that predicts a good long term result in primary PTCA. The choice of an adequate balloon size is thereby important. A ratio of diameters inflated balloon/undiseased artery $<1$ increased the restenosis risk, $1 \cdot 1-1 \cdot 3$ being optimal ${ }^{128]}$. The unpredictable resistance and histology of the plaque to be treated certainly also determines the inflation pressure needed and the extent of the resulting dissection.

For repeat PTCA higher inflation pressure and even mild intimal dissection led to more restenosis 


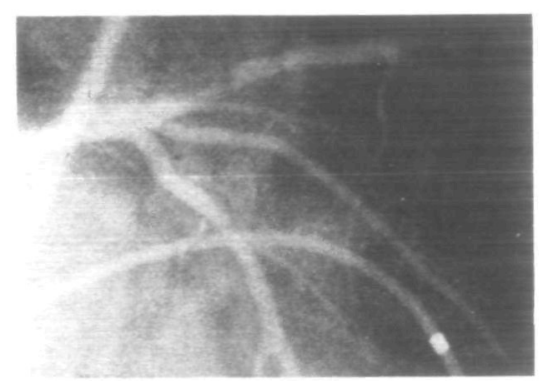

(a)

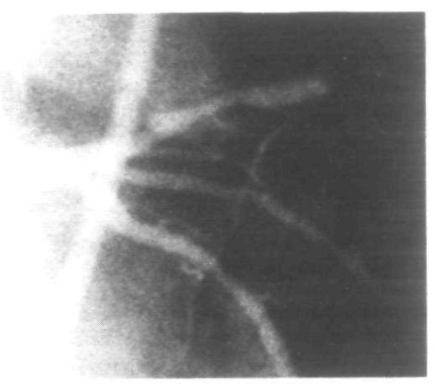

(c)

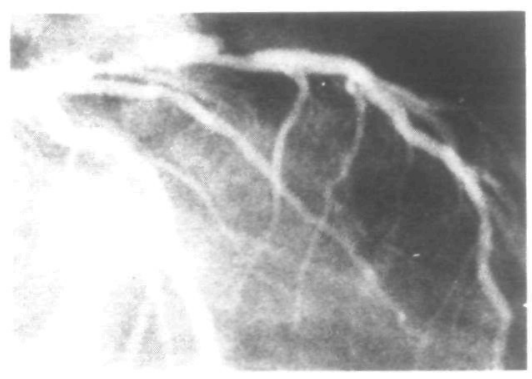

(e)

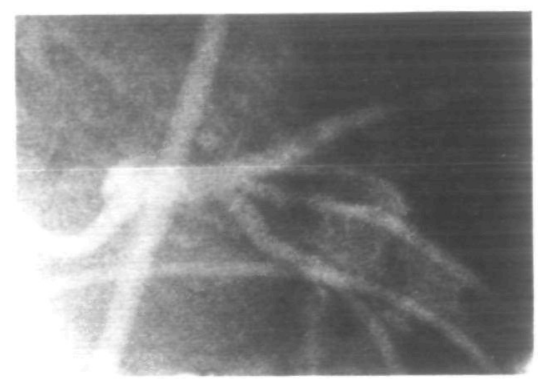

(b)

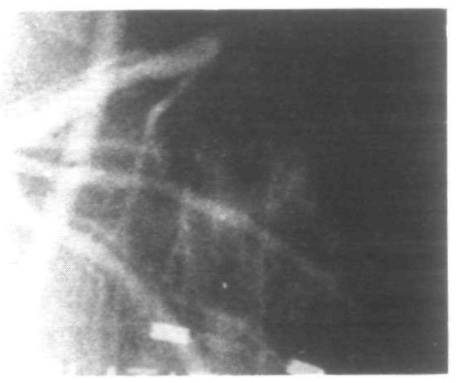

(d)

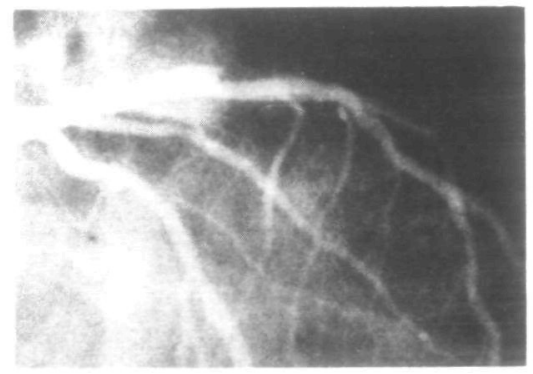

(f)

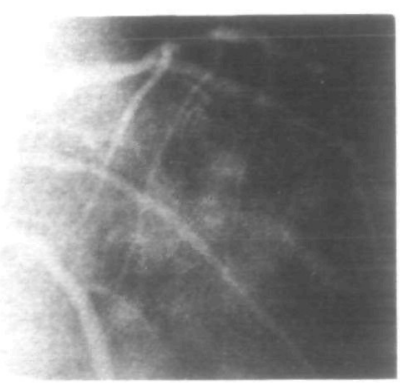

(g)

Figure 2 Angiographic pattern of restenosis post-PTCA and repeat PTCA

Sixty-three year old man with single vessel disease. The angulation for all frames is RAO $15^{\circ} / 25^{\circ}$ caudal, except for e and $\int\left(\right.$ RAO $30^{\circ}$ ). (a) April 1983 - excentric short stenosis of $75 \%$ on proximal LAD; (b) Immediate result of PTCA 1 (balloon $3.7 \mathrm{~mm}, 4 \mathrm{~atm}$ ): residual stenosis of $20 \%$, no visible dissection; (c) October 1983 - restenosis of $60 \%$, longer and smoother than the original stenosis; (d) immediate result of PTCA 2 (balloon $4.3 \mathrm{~mm}, 12$ atm): residual stenosis of $25 \%$, long dissection without impairment of flow; (e) February 1984 - restenosis of $60 \%$, long and irregular; (f) immediate result of PTCA 3 (balloon $3.5 \mathrm{~mm}, 8 \mathrm{~atm}$ ): residual stenosis of $30 \%$, no visible dissection; ( $\mathrm{g}$ ) September 1984 - control, no significant restenosis. 
in spite of a good primary result. This point deserves special attention. If we are dealing with a different, more compliable histological substrate in repeat PTCA, the use of lower inflation pressure might indeed be optimal. In PTCA on an original hard atheromatous plaque, disruption of the internal elastic membrane and overstretching of the muscular media with some cellular damage under high pressure is probably essential for success ${ }^{[37]}$. In repeat PTCA, however, it might be sufficient to distend and perhaps compress to some degree the proliferating fibrocellular neointima with lower pressure.

No drug regimen was associated with a signifcantly lower recurrence rate after primary or repeat PTCA. That was also true for other retrospective studies $^{[18,2 t]}$. According to prospective trials, aspirin is at least as effective as coumadin in preventing restenosis after PTCA $^{[38]}$ and diltiazem does not decrease the recurrence rate in patients without variant angina ${ }^{[30]}$. Calcium antagonist therapy however, seems to reduce the high restenosis risk of PTCA in patients with variant angina ${ }^{[17]}$.

\section{PATHOLOGY OF RESTENOSIS}

The difference in procedural risk factors for restenosis after primary and repeat PTCA seems rational if the histology of restenosis differs from the original lesion. Although a few histological case reports of restenosis $3-6$ months after PTCA have documented recurrent lesions indistinguishable from de novo atherosclerosis ${ }^{[39]}$ others have shown restenosis by fibrocellular proliferation only ${ }^{[40.4]}$ resembling more the experimental model ${ }^{[42]}$. Restenosis by intimal fibrous hyperplasia only has also been described after venous bypass angioplasty performed early ( 2 months) after graft insertion ${ }^{\{3 \mid}$ whereas vein graft stenoses occurring beyond one year after insertion are known to consist of typical atherosclerotic plaque $\mathrm{e}^{[44]}$. It is a common experience that restenoses are more symmetrical and smoother in their angiographic appearance (see Fig. 2) and less resistant when being dilated, suggesting that the consistency and histology indeed differ from the original lesions. The role of platelets in coating a damaged surface immediately after PTCA ${ }^{[45-47]}$ and that of thrombus organization ${ }^{[42]}$ has been demonstrated for restenosis in the animal model. Intimal proliferation of smooth muscle cells seems to be the main mechanism of recurrence in $\operatorname{man}^{[40.41 .43]}$. It can be triggered by platelet-derived growth factors, but might also be provoked by the balloon injury itself independently of serum factors ${ }^{[48]}$ and thus even under antiplatelet or anticoagulant drugs. Spasm is probably not the major stimulus of restenosis in patients without variant angina ${ }^{[30]}$, but occurs early after PTCA ${ }^{[49]}$.

\section{THIRD PTCA}

Our number of third angioplasties performed on the same restenosing segment is too small to draw firm conclusions. However, a majority of this highly selected population $(8 / 9$ in our experience, $6 / 7$ in the Atlanta report ${ }^{[24]}$ 13/23 in the series of the $\mathrm{Mid}$ America Heart Institute ${ }^{[25]}$ seems to have a favourable long term outcome. The only restenosis after PTCA 3 we experienced was on the proxımal part of a venous bypass graft.

\section{Conclusions}

Restenosis after PTCA remains a major problem. Besides some inherent risk factors such as male sex, variant angina and multivessel disease, procedural factors are the main determinants of long-term success in PTCA. An optimal primary result with a minimal residual stenosis, that might well include mild intimal tearing, is important for first PTCA, whereas a voidance of any visible dissection by using lower inflation pressure on a restenosis of probably different histology could improve the long-term outcome of repeat PTCA. Repeat PTCA in patients with restenosis after a first procedure has a high primary success rate, and complications are rare. Although the restenosis rate after a second angioplasty is at least as high as after the first intervention, $70 \%$ of the patients with repeat PTCA have a successful long-term outcome, if one includes third interventions. Women seem to do better than men. Thus, repeat angioplasty should be considered as an integral part of PTCA therapy.

\section{Addendum}

Up to 15 November 1984,136 coronary segments in 117 patients were redilated because of a restenosis at the Montreal Heart Institute. The overall primary success rate was $91 \%$. Of the 95 segments successfully dilated before 15 May $1984,82(86 \%)$ were angiographically controlled within 6 months (by 15 November). Restenosis $\geqslant 70 \%$ was present on $27(33 \%)$ of the segments. No recurrence occurred after a successful second PTCA in women $(N=17)$.

The above conclusions, therefore remain valid for our entire experience.

We acknowledge the excellent secretarial assistance of Heidi Schüppbach in the preparation of this manuscript. 


\section{References}

[1] Gruentzig AR. Transluminal dilatation of coronaryartery stenosis (letter to the editor). Lancet 1978; 1: 263.

[2] Gruentzig AR, Senning A, Siegenthaler WE. Nonoperative dilatation of coronary artery stenosis. N Engl J Med 1979; 301: 61 .

[3] Scholl JM, Chaitman BR, David PR el al. Exercise electrocardiography and myocardial scintıgraphy in the serial evaluation of results of PTCA. Circulation 1982; 66: 380.

[4] Hirzel HO, Nuesch K, Gruentzag AR, Horst W, Krayenbuehl HP. Thallium 201 exercise scintigraphy after percutaneous transluminal coronary angioplasty of coronary artery stenosis. Med Clinics of North America 1980; 64: 163.

[5] Williams DO, Riley RS, Singh AK, Most AS. Coronary circulatory dynamics before and after successful angioplasty. J Am Coll Cardiol 1983; 1: 1268.

[6] O'Neill WW, Wolton JA, Bates ER et al Criteria for successful coronary angloplasty as assessed by alterations in coronary vasodilatory reserve J Am Coll Cardiol 1984; 3: 1382.

[7] Bentivoglio LG, Van Raden MJ, Kelsey SF, Detre KM. PTCA in patients with relative contraindications: Results of the NHLBI PTCA Registry. Am J Cardiol 1984; 53: 82C.

[8] Mock MB and other participants in NHLBI PTCA registry: PTCA in the elderly patient. Experience in the NHLBI PTCA registry. Am J Cardıol 1984; 53: 89C.

[9] Dorros G, Stertzer SH, Cowley MJ, Myler RK. Complex coronary angioplasty: multiple coronary dilatations. Am J Cardiol 1984; 53: 126C.

[10] Vhetstra RE, Holmes DR, Reeder GS et al. Balloon angioplasty in multivessel coronary artery disease. Mayo Clin Proc 1983; 58: 563.

[11] Mata LA, Bosch X, David PR, Rapold HJ, Corcos T, Bourassa MG. Clinical and anglographic assessment 6 months after double percutaneous coronary angioplasty. J Am Coll Cardiol 1985; 6: 1239.

[12] Faxon DP, Detre KM, McCabe CH et al. Role of PTCA in the treatment of unstable angina. Am J Cardiol 1984; 53: $131 \mathrm{C}$.

[13] Block PC, Cowley MJ, Kaltenbach M, Kent FM, Simpson J. Percutaneous angioplasty of stenoses of bypass grafts or of bypass graft anastomotic sites. Am J Cardiol 1984, 53: 666.

[14] Holmes DR, Vlietstra RE, Reeder GS, Bresnalan JF, Smith HC, Bove AA. Angioplasty in total coronary artery occlusion. J Am Coll Cardiol 1984; 3: 845.

[15] Hartzler GO, Rutherford BD, McConahay DR. PTCA: Application for acute myocardial infarction. Am J Cardiol 1984, 53: 117C

[16] Hitchcok JF, Robes de Medina E. Angıoplasty of the main left coronary artery for isolated left main coronary artery disease. Am J Cardiol 1982; 49: 956 (Abstr).

[17] Corcos T, David PR, Bourassa MG el al. PTCA for the treatment of variant angina. J Am Coll Cardiol 1985; 5 : 1046.

[18] Holmes DR and other participants in the NHLBI PTCA registry. Restenosis after PTCA: a report from the PTCA registry of the NHLBI. Am J Cardiol 1984; 53: $77 \mathrm{C}$.

[19] Gruentzig AR, Meier B. PTCA. The first five years and the future. Int J Cardiol 1983; 12: 3.
[20] Kaltenbach M, Kober G, Scherer D, Vollbracht C. Recurrence rate after successful coronary angioplasty Eur Heart 1985; 6: 276.

[21] Leimgruber PP, Roubin GS, Hollman J et al Restenosis after successful coronary angioplasty in patients with single vessel disease. Circulation 1986; 73: 710.

[22] Hollman J, Galan K, Franco I et al: Recurrent stenosis after coronary angioplasty. J Am Coll Cardiol 1986; 7: $20 \mathrm{~A}$ (Abstr).

[23] Williams DO, Gruentzig AR, Kent KM, Detre KM, Kelsey SF, To T. Efficacy of repeat PTCA for coronary restenosis. Am J Cardiol 1984; 53: 32C.

[24] Meier B, King SB, Gruentzıg AR et al. Repeat coronary angioplasty. J Am Coll Cardiol 1984; 3:463.

[25] Giorgi LV, Hartzler GO, Rutherford BD, McConahay DR. Should repeat PTCA be performed on patients with multiple recurring restenoses? Circulation 1984; 70 (Suppl II) II-177 (Abstr).

[26] Fleck E, Dacian S, Dirschinger J, Hall D, Rudolph W. Quantitatuve changes in stenotic coronary artery lesions during follow-up after PTCA. Circulation 1984; 70 (Suppl 1I) 11-176 (Abstr).

[27] Bourassa MG, David PR, Guiteras Val P. Percutaneous transluminal coronary angioplasty. In: Rowlands DJ, ed. Recent Advances in Cardiology 9. Edinburgh: Churchlll Livingstone, 1984; 193-212.

[28] Duprat G, David PR, Lespérance J et al. An optimal size of balloon catheter is critical to angiographic success early after PTCA. Circulation 1984; 70 (Suppl II) II-295 (Abstr).

[29] David PR, Renkin J, Moise A, Dangoisse V, Guiteras PV, Bourassa MG. Can patient selection and optımization of technique reduce the rate of restenosis after PTCA. J Am Coll Cardiol 1984; 3: 470 (Abstr).

[30] Corcos T, David PR, Renkin J et al. A randomized trial of Diltiazem for prevention of restenosis after PTCA. Am Heart J 1985; 109: 926.

[31] Waters DD, Miller DD, Szlachcic J et al. Factors influencing the long term prognosis of treated patients with variant angina. Circulation 1983; 68: 258.

[32] Faxon DP, Kelsey SF, Ryan TJ, McCabe CH, Detre K. Determinants of successful PTCA. Report from the NHLBI registry. Am Heart J 1984, 108: 1019.

[33] Meier B, Gruentzig AR, King SB et al. Higher balloon dilatation pressure in coronary angioplasty. Am Heart J 1984; 107: 619 .

[34] Douglas JS, King SB, Jones E et al. Reduced efficacy of coronary bypass surgery in women. Circulation (Suppl II) $1981 ; 11: 11$.

[35] Loop FD, Golding LR, MacMillian JP et al. Coronary artery surgery in women compared with men: analysis of risks and long term results. J Am Coll Cardıol 1983; 1: 383.

[36] Douglas JS, Grüntzig AR, King SB et al. PTCA in patients with prior coronary bypass surgery. J Am Coll Cardiol 1983; 2: 745.

[37] Block PC. Mechanısm of transluminal angioplasty. Am J Cardiol 1984; 53: 69C

[38] Thornton MA, Gruentzig AR, Hollman J, King SP, Douglas JS. Coumadin and Aspirin in prevention of recurrence after transluminal coronary angioplasty: a randomized study. Circulation 1984; 69: 721 .

[39] Waller BF, McManus BM, Kishel JC. Sudden death 90 to 180 days after PTCA: Severe narrowing by athero- 
sclerotic plaque at necropsy at the site of previous angioplasty. Circulation 1982; 66 (Suppl II) II: 4.

[40] Essed CE, Van den Brand M, Becker AE. PTCA and early restenosis: Fibrocellular occlusion after wall laceration. Br Heart J 1983; 49: 393.

[41] Austin GE, Ratliff NB, Hollman J el al. Intımal proliferation of smooth muscle cells as an explanation for recurrent coronary artery stenosis after PTCA. J Am Coll Cardiol 1985; 6: 369.

[42] Faxon DP, Sanborn TA, Weber VJ et al. Restenosıs following transluminal angioplasty in experimental atherosclerosis. Atherosclerosis 1984; 4: 189.

[43] Waller BF, Rothbaum DA, Garfinkel HJ, Ulbright TM, Linnemeier TJ, Berger SM. Morphologic observations after percutaneous transluminal balloon angioplasty of early and late aortocoronary saphenous vein bypass grafts. J Am Coll Cardiol 1984; 4: 784.

[44] Lie JT, Lawrie GM, Morris GC. Aortocoronary bypass saphenous vein graft atherosclerosis. Anatomic study of 99 veın grafts from normal and hyperlipoproteinemic patients up to 75 months postoperatively. Am J Cardiol 1977; 40: 906 .
[45] Pasternac RC, Baughman KL, Fallon JT, Block PL. Scanning electron microscopy after coronary transluminal angioplasty in experimental atherosclerosis. Arteriosclerosis $1984 ; 4 \cdot 189$.

[46] Steele PM, Chesebro JH, Stanson AW. Balloon angioplasty: natural history of the pathophysiological response to injury in a pig model. Circulation Res 1985; 57: 105 .

[47] Lam J, Chesebro JH, Steele PM, Badımon L, Fuster V. Production of tears into media during arterial angioplasty predisposes to platelet thrombus deposition. J Am Coll Cardiol 1985; 5. 520 (Abstr).

[48] Grunwald J, Haudenschild CC. Intimal injury in vivo activates vascular muscle cell migration and explant outgrowth in vivo. Arteriosclerosis $1984 ; 4: 183$.

[49] Hollman J, Austin GE, Grüntzig AR et al. Coronary artery spasm at the site of angioplasty in the first two months after successful PTCA. J Am Coll Cardiol 1983; 2: 1039 . 